УДК: 351: 323 15. 001.8 (477)

DOI: https://doi.org/10.31470/2518-7600-2021-13-311-330

INFLUENCE OF SOCIOECONOMIC FACTORS ON ETHNOPOLITICAL PROCESSES: THEORETICAL AND METHODOLOGICAL FUNDAMENTALS OF RESEARCH

\title{
ВПЛИВ СОЦІАЛЬНО-ЕКОНОМІЧНИХ ЧИННИКІВ НА ЕТНОПОЛІТИЧНІ ПРОЦЕСИ: ТЕОРЕТИКО- МЕТОДОЛОГІЧНІ ЗАСАДИ ДОСЛІДЖЕННЯ
}

\section{ВЛИЯНИЕ СОЦИАЛЬНО-ЭКОНОМИЧЕСКИХ ФАКТОРОВ НА ЭТНОПОЛИТИЧЕСКИЕ ПРОЦЕССЫ: ТЕОРЕТИКО-МЕТОДОЛОГИЧЕСКИЕ ОСНОВЫ ИССЛЕДОВАНИЯ}

\section{Леся Ковач}

кандидат історичних наук, науковий співробітник відділу національних меншин lesakovac6@gmail.com ORCID: 0000-0002-0872-0219 Researcher ID: 00085002 Інститут політичних i етнонаціональних досліджень ім. І.Ф. Кураса НАН України, вул. Генерала Алмазова, 8, м. Київ-11, 01011
Lesia Kovach, Ph.D. in Historical Science, Research Scientist of the Department of National Minorities

lesakovac6@gmail.com ORCID: 0000-0002-0872-0219 Researcher ID: 00085002 Kuras Institute of Political and Ethnic Studies of the National Academy of Sciences of Ukraine, General Almazov Str., 8, Kyiv,01011

\section{ABSTRACT}

Theoretical and methodological bases of influence of social and economic factors on ethnopolitical processes in segmented societies are generalized and analyzed. The general regularities 
and possible consequences of the direction of their development for the general political situation in the country are revealed. Most attention is paid to conflict theories, functional approach, theories of modernization and culturological aspects of socio-economic inequality. Their critical analysis is carried out. The significant heuristic potential of existing theories and the need for their practical use are emphasized. It is noted that in most theoretical approaches, ethnicity is seen as a symbolic and social capital that can be used by political actors to achieve their political and economic goals both within the country and abroad. In this regard, it is pointed out the need to take into account the socioeconomic characteristics of ethno-national groups in the system of statistical data processing by the State Statistics Committee of Ukraine. This will make it possible to monitor the processes of ethnic social stratification in dynamics and provide research with appropriate information support. It is noted that taking into account the achievements of scientific knowledge and in order to increase the effectiveness of state ethnic policy, the application of the approach(conditionally it can be called «status quo»), which involves the transition from the paradigm "we - they" to the paradigm "I and we». The main task of this approach is to ensure that every citizen can freely and fully participate in the sociopolitical life of the nation, have opportunities for social mobility, while maintaining their own regional, local, national-cultural, spiritual, religious and personal identity.

Keywords: ethnopolitics, theoretical and methodological approaches, socio-economic factors of ethnic mobilization, ethnicity.

Постановка проблеми. Однією 3 найважливіших функцій політичної науки крім вирішення суто теоретичних завдань - систематизації, аналізу, узагальнення, оцінки та інтерпретації політичних явищ та процесів $\epsilon$ прикладна функція, яка передбачає механізми реалізації набутого політичного знання, раціоналізацію управління політичними 
процесами. Особливо це стосується сфери міжнаціональних відносин, які на сучасному етапі світового розвитку постають чи не найголовнішим чинником дестабілізації політичної ситуації та виникнення військових конфліктів у різних куточках світу. Причини міжнаціональних конфліктів можуть бути різними, починаючи від проблем всередині країни, i закінчуючи впливом геополітичних інтересів та процесами глобалізації. Особливої уваги потребують соціально-економічні потреби етнічних спільнот, адже протиріччя, що виникають 3 приводу володіння матеріальними і суспільними ресурсами, на думку багатьох науковців, є одними з головних у виникненні міжнаціональних протиріч та конфліктів.

Враховуючи зазначене, об'сктом дослідження $€$ соціально-економічні чинники та їх вплив на етнополітичні процеси, предметом - теоретичні напрацювання світової та вітчизняної науки з зазначеної проблематики.

Відтак метою роботи є критичний та узагальнюючий аналіз теоретико-методологічних підходів щодо впливу соціально-економічних чинників на процеси консолідації (зміцнення національно-громадянської єдності) та дезінтеграції (поширення відцентрових тенденцій, етнічної сегрегації включно з виникненням сепаратистських ідей та рухів); обгрунтування системи заходів, спрямованих на підвищення ефективності державної етнонаціональної політики та окреслення перспективних напрямів подальших наукових пошуків.

Аналіз основних досліджень і публікацій. Вивчення теми причинно-наслідкових зв'язків між чинниками соціальноекономічного характеру, політизацією та мобілізацією етнічності має тривалу наукову традицію як у зарубіжній, так і у вітчизняній етнополітичній науці. Зокрема, ця тема стала об'єктом дослідження П. Бурдьє у його статті «Форми капіталу», опублікованій у 1983р., в якій до наукового обігу було введено поняття соціального капіталу для позначення соціальних зв'язків, які можуть виступати ресурсом для 
отримання різноманітних вигод (Бурдье, 1983); американських вчених: П. Ван ден Берге (стверджував, що всі військові конфлікти, соціальна нерівність, класова боротьба, злочинність кореняться у біологічних особливостях людської природи, а такі символи як мова, релігія колір шкіри, тощо є показниками біологічної спорідненості) (Van den Berghe, 1981), Е. Бонасіч (міграційна проблематика) (Bonacich,1972) російських Ю. Арутюняна, Л. Дробижевої, А. Сускопова (широкий комплекс питань, пов'язаний 3 соціальним розвитком етнічностей та причинами їхньої етномобілізації) (Арутюнян, Дробижева, Сускопов, 1999), В. Тишкова (розвивав модерністські теорії, зокрема думку, що все те, що звикли пов'язувати з етнічними чинниками або етнічними традиціями зовсім немає жорсткої регламентації, а визначається історичним досвідом країни, держави, політичною системою в якій ця група знаходиться: «Загальна соціальна і економічна культура, - писав він, - яка формується в межах держави значно сильніше впливає на процеси ринкової трансформації, ніж партикулярні етнічні і культурні традиції») (Тишков, 2005), Л. Дробіжжевої (основна увага зосереджена на статусних уявленнях етнічних груп та чинниках, які впливають на їх формування), українських - Т. Рудницької (функціональна парадигма) , В. Котигоренка (конфліктологічний підхід), В. Свтуха (об’єктом уваги дослідника виступає поселенська структура етнічних спільнот в регіонах України та досліджується вплив етнічного чинника на формування регіональних ринків праці в країні), М. Дністрянського (проаналізовано економічні чинники етнополітичної географії та геополітичних орієнтацій мешканців українських регіонів), I. Зварича (дав визначення таким поняттям як «регіон - донор» i «депресивний регіон», окреслив їх основні критерії та конфліктологічний потенціал) (Зварич, 2009). Крім уже згаданих авторів, варто відмітити праці I. Кураса (Курас, 2004), О. Майбороди (Майборода, 2005: 30-48) ， В. Арбєніної (Арбєніна, 2007). 
У вітчизняній етнополітичній науці помітне місце займає колективна монографія співробітників відділу національних меншин Інституту політичних і етнонаціональних досліджень ім.. І. Ф. Кураса НАН України «Етнополітичні процеси в Україні: регіональні особливості», яку було виконано під керівництвом М. Панчука.

Соціально-економічна складова етнополітичних процесів у цій праці досліджується шляхом аналізу рівня економічного розвитку регіонів, стану соціального забезпечення, етнічного складу населення, його поселенської структури, компактності/дисперсності розселення, міграційних переміщень - як зовнішніх, так i внутрішніх. В роботі міститься не лише кількісний аналіз досліджуваних явищ та процесів, але й їх якісні характеристики пов'язані 3 етнокультурними традиціями, які змінюються та трансформуються внаслідок взаємодії представників різних етнічних груп у конкретному соціально-економічному середовищі (Етнополітичні процеси в Україні: регіональні особливості: Монографія, 2011).

Виклад основного матеріалу. На думку Дж. Ролса, автора монографії «Теорія справедливості», наявність нерівності сама по собі не є несправедливістю, вона виникає природно, первісно. Вона стає такою лише тоді, коли «порушується» ідея «справедливості як чесності», як принципу рівного права на свободу та рівномірний розподіл цінностей суспільства (Джон Роулз, 1971).

«Оглядаючи причини міжетнічного конфлікту, зазначають українські дослідники В. Свтух та А. Попок, можна зробити висновок, що глобальною причиною конфліктів $\epsilon$ змагання соціальних груп (а етнічна спільнота є одним з їі різновидів) за здобуття гідних ніш у процесі суспільного розвитку країни. У поліетнічних країнах ці змагання розвиваються на базі етнічного чинника. Оскільки можливості таких ніш на певному статистичному відтинку розвитку суспільства обмежені (мається на увазі той факт, що вони 
зазвичай зайняті представниками етнічних спільнот з більш потужним силовим полем), то конкурентне співіснування різних етнічних спільнот може набирати гостроти й досягати... стану етнічного антагонізму, від якого лише крок до виникнення етнічного конфлікту» (Євтух В., Попок А., 2003: 16).

У деяких поліетнічних суспільствах, де чітко окреслюються етнічні сегменти (за характером поселення, специфікою зайнятості), етнічний антагонізм виникає й унаслідок витіснення із певних сфер або недопущення у ці сфери інші етноси, окрім тих, які свого часу опанували відповідну сферу діяльності. Особливо чітко це фіксується у сфері так званого малого бізнесу у Сполучених Штатах Америки, Канаді, Великобританії, Австрії (скажімо, вихідці $з$ Кореї контролюють практично всі пункти торгівлі овочами у Нью-Йорку; віденські торговці пресою є виключно іммігранти 3 країн південно-східної Азії та арабського регіону).

Проте факт існування відмінних за місцем та роллю в суспільстві груп може бути потрактований не лише як прояв соціальної нерівності, а й як функціонально виправдане взаємодоповнення різними групами одна одної, особливо, коли йдеться про трудову сферу. В цьому плані привертають увагу дослідження американських соціологів середини ХХ століття Р. Лінтона, Т. Парсонса, К. Девіса, У. Мура та інших. Нерівна винагорода, включаючи прибуток i статус, вважають функціоналісти, є необхідним механізмом, за допомогою якого суспільство гарантує, що найважливіші для суспільства місця посядуть найкваліфікованіші люди.

У вітчизняній науковій думці функціональний підхід представлений працями Т. Рудницької (Рудницька, 1996: 111133), яка стверджує, що етнічний склад галузей господарства, що склався в Україні на рубежі 80-90-х років XX століття, пропорції професійно-кваліфікаційного складу зайнятих у них свідчить про існування у суспільстві етнокультурного поділу праці. «Займаючи певну нішу в трудовій сфері суспільства, - 
пише дослідниця, - різні етнічні спільноти доповнюють одна одну, створюючи цілісний трудовий потенціал населення держави. Наприклад, значна частина поляків зайнята у лісовому господарстві, що пов'язано з розташуванням їхнього традиційного компактного проживання в українському Поліссі. Галузеві вподобання болгар реалізовані у заготівельній галузі, а в греків - у сфері торгівлі та громадського харчування. Такий розподіл склався під впливом давніх етнокультурних традицій і тому, вважає Т. Рудницька, суспільству недоцільно ліквідувати ці трудові етнічні ніші.

Водночас переконана Т. Рудницька, це, безумовно, не означає заперечення необхідності створення у суспільстві таких умов, які б сприяли вертикальній мобільності тих груп, які поки що є на нижчих щаблях етнічної ієрархії і не тільки за професійно-кваліфікаційними критеріями, а й перш за все, 3 погляду матеріального стану, участі в управлінні тощо» (Рудницька, 1996: 111-133).

Позитивну роль культурного розподілу праці, також підкреслює Б. Свтух, але із застереженням, що такий розподіл $\epsilon$ позитивним механізмом регулювання виробничих відносин у поліетнічному суспільстві лише за умов нормального функціонування економіки і відсутності дискримінації за етнічною ознакою (Свтух, 2003: 178).

Основні труднощі, 3 якими може зіткнутися функціональне вивчення етнічної взаємодії, це питання про те, виходячи з якого цілого потрібно пояснювати факти і впливи? Чи етнічні групи є окремими самостійними системами, чи підсистемами поліетнічного цілого? I чи потрібно вважати поліетнічне суспільство особливим типом політичної системи? Серед інших недоліків функціонального підходу дослідниками називаються: відсутність уваги до влади, багатства і власності як підстав стратифікації; перебільшення індивідуальнодосяжницького характеру нерівності і недооцінка чинника спадковості статусної позиції; ігнорування боротьби, яку ведуть між собою різні страти за владу, престиж і матеріальні цінності. 
Близькою до функціонального напрямку $\epsilon$ «теорія внутрішнього колоніалізму» американського етносоціолога М. Хектера (Вашингтонський університет). Згідно з цією теорією представники тих чи інших етносів мають нахил до певного виду розумової чи фізичної праці і займаючись саме нею, ефективно досягають найпомітніших успіхів. За умов нормального функціонування економіки й адекватного структурування ринку праці, коли існує великий діапазон вибору сфер зайнятості й відсутня дискримінація не домінуючих груп населення за етнічними ознаками, такий поділ $є$ позитивним механізмом регулювання виробничих відносин у поліетнічному суспільстві. Однак у кризових економічних ситуаціях, коли падає обсяг виробництва, зростає рівень безробіття, а відтак і конкуренція на ринку праці, то домінуюча більшість намагається зміцнити своє становище. За іммігрантами закріплюються сфери малокваліфікованої, фізично важкої, брудної і низькооплачуваної праці, що усвідомлюються ними як дискримінація та стає причиною їхньої етномобілізації.

На іншу сторону культурного поділу праці звертає увагу російський дослідник В. Ільїн. На його думку, різні етноси у боротьбі за виживання виявляються неоднаково пристосованими до умов певного суспільства, перш за все, завдяки специфіці своєї культури (традиціям, нормам, цінностям, тощо). У підсумку, одна етнічна культура сприяє вертикальній соціальній мобільності, друга - навпаки, перешкоджає їй. Тому, переконує В. Ільїн, доцільно розмежовувати етносоціальну стратифікацію у чистому вигляді та вторинну етносоціальну стратифікацію. Про етносоціальну стратифікацію у чистому вигляді, можна говорити у тому випадку, коли етнічні спільноти цілеспрямовано поставлені у нерівне становище у державній ієрархії та стають об’єктом привілеїв або дискримінації. Вторинна етносоціальна стратифікація виникає тоді, коли етнічні межі збігаються 3 природними зонами, галузевою зайнятістю та поселенською 
структурою. Унаслідок цього етносоціальна нерівність $є$ результатом нерівності регіонів, галузей господарства, місця проживання (місто/село) (Ильин, 1996: 309-310).

Етносоціальна проблематика широко розроблялась й іншими російськими дослідниками. Серед найбільш грунтовних необхідно відзначити праці В. Тишкова (Тишков, 2005) та Л. Дробіжевої. Під керівництвом останньої, зокрема, вийшла колективна монографія, під назвою «Социальное неравенство этнических групп: представления и реальность» (Социальное неравенство этнических групп: представления и реальность, 2002). В ній автори дослідження зробили спробу 3'ясувати низку питань, а саме: наскільки виправданими є уявлення про етнічну дискримінацію і про етнокультурні перешкоди на шляху трансформаційних процесів у Російській Федерації? Чому ситуація відбору на ринку праці, яка $є$ неминучою в умовах соціально-економічної конкуренції, сприймається суспільною свідомістю як прояв нерівності, і які реальні відмінності в розподілі багатства, престижу, влади в етнічних групах? Наскільки впливає етнічність на розміщення людей у стратифікаційній ієрархії сучасного російського суспільства?

Наприкінці 70-х рр. ХХ ст. у науковій думці значної популярності набули теорії модернізації. Вважалось, що модернізація (перехід від традиційного типу суспільства до індустріального) забезпечує людині більше свободи. Цього ж вимагає і неокласична економічна теорія, в якій наголошується, що ринок має бути максимально вільним i, що будь-яке його інституційне обмеження є небажаним.

У світлі цих уявлень етнічність, яка мобілізується модернізацією, виступає перешкодою такому вивільненню особистості, і як пережиток минулого, приречена на зникнення 3 прийняттям західного способу життя. Вважалось, що для нівелювання етнічного фактору достатньо правильно керувати ресурсами і заохочувати економічне зростання. Центральним положенням теорій 1950-1970-х років було твердження, що 
етнічні конфлікти, націоналізм є кризовими явищами не до кінця змодернізованого суспільства i, що остаточне становлення такого суспільства буде його кінцем. Очікування, що економічне зростання покладе кінець тероризму i фундаменталізму, зокрема, стосовно Ізраїлю висловлювались Ш. Пересом. А в Північній Ірландії багато хто думав так: «дайте їм роботу, і вони кинуть свою зброю» (Р. Дарендорф, 2006.).

Однак 3 часом виявилося, що незважаючи на модернізацію і прискорене економічне зростання, значення етнічного чинника у світі не тільки не зменшилося, а навіть посилилось. Також було встановлено, що у різних країнах модернізація може відбуватися шляхом, відмінним від західного. У зв'язку з цим було висловлено припущення, що збереження етнічного чинника спричинене його неабиякою вигодою. Оскільки влада і багатство можуть бути надбанням відносно невеликої групи людей (еліти), що як правило самостійно неспроможна витримати виснажливу боротьбу за свої інтереси, еліта мобілізує «не елітні» маси для боротьби за ці інтереси. Зручним інструментом такої мобілізації і виступає етнічність, яка дає змогу подати справу таким чином, що маси борються за честь і гідність свого народу, за землі й пам'ять предків тощо, а не за корисливі, а нерідко й гедоністичні інтереси еліти. Націоналізм, зазначає британський дослідник Р. Роговські, майже завжди грунтується на прискіпливій оцінці власного інтересу і реальної суспільної ситуації (а не $є$ наслідком історії або ілюзіï) i, що він найтіснішим чином пов'язаний з суспільним поділом праці та змінами в цьому поділі». Його посилення є результатом природної конкуренції етнічних груп на різноманітних ринках, які постійно змінюються (Rogovsci, 1989). Крім цього, нацьковуючи одну етнічну групу на іншу, панівний клас сіє розбрат між людьми, які могли б об'єднатися і виступити проти нього, а головне дискусії навколо етнічних проблем відволікають увагу людей від боротьби за право повноцінної участі у владі та управлінні економікою (Tabb, 2002). 
Представники конфліктологічного (Л. Козер, К. Боулдінг, Р. Дарендорф) підходу вважають, що етнічна нерівність присутня у будь-якому поліетнічному суспільстві. Адже етнічні групи, як і всі інші соціальні групи, утворюють певну ієрархію (етносоціальну стратифікацію), і вже у самій цій обставині закладено потенціал конфлікту. Причиною ж конфліктів $\epsilon$ постійні зміни в етнічній стратифікації суспільства.

На думку В. Котигоренка, який протягом тривалого часу займається дослідженням етнічних протиріч і конфліктів в Україні, вивченням специфіки розвитку етнодемографічної та етносоціальної структури українського суспільства, потенційна конфліктогенність етнонаціональних відмінностей полягає не так у факті їх наявності, скільки у векторах загальної соціально-економічної динаміки. «Суспільну напругу i конфлікти, - пише вчений, - продукують не етносоціальні відмінності як такі, а передовсім соціально-економічні негаразди, здатні посилювати суспільне невдоволення, яке за певних умов і певними силами може бути каналізованим у сферу міжетнічних взаємин, ставлення етнічних спільнот до держави та іï політики» (Котиоренко, 2004: 152) .

В умовах глобалізації значної популярності набув інтеракціоністський підхід, основи якого були закладені працями американських соціологів Ч. Кулі та Дж. Міда, Т. Шибутані, В. Хеслі та іншими.

Етнічні групи, стверджувала американська дослідниця В. Хеслі, уособлюють собою закриті соціокультурні одиниці. Однак, оскільки вони об'єднані в одній державі, повинні періодично взаємодіяти на загальних для всіх ринках і в загальній для всіх політичній системі. «Така взаємодія в рамках єдиної політико-економічної сфери, - пише В.Хеслі, призводить до того, що одна $з$ груп починає панувати над іншими. Але коли об'єднуються відмінні одна від одної інституціональні системи - і коли цінності та зразки поведінки здаються несумісними - домінуюча група, як правило, намагається примусити меншинні групи до асиміляції i 
прийняття панівних культурних норм» (Етнополітичний конфлікт: URL: https://subject.com.ua/political/dict/529.html). За таких умов інтеракції виникають як результат дії різних факторів. Так, у випадку диверсифікації етнополітичних ситуацій очевидно, що суб'єкт-об'єктні стосунки на етапі розпаду держави постають як наслідок боротьби за дефіцитні чи іншого роду ресурси, конкуренції за здобуття найвигідніших умов «облаштування» в нових етнополітичних організмах, соціалізації в них. В інших ситуаціях взаємодія виникає як наслідок функціональної взаємозумовленості груп або ж ініціатив однієї з них, які безпосередньо чи опосередковано стосуються інтересів «інших», з одного боку, та їхньої реакції на загрозу «ми - інтереси», з іншого (Етнополітичний конфлікт: URL: https://subject.com.ua/political/dict/529.html).

Для прогнозування та моделювання етнополітичних наслідків, які можуть мати місце в результаті збільшення кількості нелегальних мігрантів, що особливо актуально для Україні в умовах катастрофічного зменшення їі населення, неабияке значення мають праці Е. Бонасіч автора теорії так званого «розколотого ринку праці».

На її переконання існують три групи суб'єктів (з різними матеріальними інтересами та потребами), які й утворюють «розколотий ринок праці»: працедавці, високооплачувані робітники, низькооплачувані робітники. Працедавці зацікавлені у тому, щоб найняти робітника за меншу плату. Тому вони охоче використовують працю етнічних мігрантів, щоб знизити ціну робочої сили, що, природно суперечить інтересам робітників з числа етнічної більшості та стимулює їхню мобілізацію проти груп меншості. В результаті виникає етнічний антагонізм, який може розвиватися в кількох напрямках: 1) витіснення низькооплачуваних робітників 3 ринку праці; 2) формування елементів «кастової системи». Перший варіант можливий за умови, коли низькооплачувані робітники є нелегальними мігрантами, а їхня кількість є незначною. Другий - коли нелегальних мігрантів багато і їх не 
можна позбутися. У цьому випадку високооплачувані робітники монополізують певні види праці та всіляко обмежують можливості низькооплачуваних робітників підвищити свою кваліфікацію, що неодмінно веде до конфлікту.

Отже більшість концепцій, що перебувають в сучасному науковому полі, хоч і мають недоліки, містять евристичний потенціал i можуть бути продуктивно використані для розробки державної стратегії консолідації українського суспільства. Перспективним видається підхід (умовно його можна назвати «status quo»), який передбачає забезпечення рівних можливостей і вільної конкуренції для різних сегментів українського соціуму, перехід від парадигми «ми - вони» до парадигми «я і ми». Основне завдання такого підходу - досягти того, щоб кожний громадянин міг вільно і в повній мірі брати участь в суспільно-політичному житті нації, одночасно зберігаючи свою власну регіональну, локальну, національнокультурну, духовно-релігійну та особистісну ідентичності; забезпечення можливостей соціальної мобільності громадян України безвідносно від їхньої національності належності та ідентифікаційних відмінностей. Для реалізації такого підходу слід передбачити урахування соціально-економічних характеристик етнонаціональних груп в системі статистичної обробки даних Держкомстатом України, що важливо для підготовки та ухвалення управлінських рішень, а також прогнозування розвитку етнополітичної ситуації в країні. Також доцільно створити архів відповідної інформації, що дозволить відстежувати процеси етносоціальної стратифікації в динаміці та забезпечить наукові пошуки відповідною інформаційною підтримкою. Важливим $є$ й постійний моніторинг доступу регіональних еліт до політичних, економічних та інших соціально важливих ресурсів, виявлення їхніх політичних орієнтацій та їхнього бачення системи державно-політичного устрою країни. При цьому, потрібно пам'ятати, що етнічність - це символічний і соціальний 
капітал, який можна використати для мобілізації людей переслідуючи при цьому різні цілі, включаючи боротьбу за владу, контроль над ресурсами, економічні прибутки та власність як всередині країни, так і на глобальному рівні. А тому наукові дослідження, пов'язані з соціально-економічними характеристиками етнічних груп, не лише важливі для забезпечення суспільно-політичної стабільності в країні, але й життєво необхідні для збереження їі територіальної цілісності та суб’єктності в системі міжнародних відносин.

\section{ДЖЕРЕЛА ТА ЛІТЕРАТУРА}

1. Бурдье П. Формы капитала. 1983. URL: https://gtmarket.ru/library/articles/2601

2. Van den Berghe, P. The Ethnic Phenomenon. Westport: Greenwood Press, 1981. 318 p.

3. Bonacich E. A Theory of Ethnic antagonism. The Split Labor Market. American Sociological Review. 1972. Vol.37. No.5 P.547 - 559 .

4. Арутюнян Ю., Дробижева Л., Соскопов А. Этносоциологияю Москва: Аспект-Пресс, 1999. 271 с.

5. 5. Тишков В. Рыночная экономика и этническая среда. Общество и экономика, 2005. №12. URL. Режим доступу: http://www.demoscope.ru/weekly/2007/0271/analit03.php 2.

6. Зварич I. Етнополітика в Україні: регіональний контекст. Київ: Дельта, 2009. 320 с.

7. Курас I. Етнополітологія. Перші кроки становлення. Київ: Генеза, 2004. 736 с.;

8. Майборода О. Етнопрофесійна структура українського суспільства: тенденції змін та їній вплив на міжетнічні відносини. Наукові записки Інституту політичних i етнонаціональних досліджень НАН України. Київ, 2005. Вип. 27. С. $30-48$.

9. Арбєніна В. Етносоціологія. Підручник. Харків, 2007: Харківський національний університет імені В.Н. Каразіна, $160 \mathrm{c}$. 
10. Етнополітичні процеси в Україні: регіональні особливості: Монографія. Київ, Інститут політичних i етнонаціональних досліджень ім. І. Ф. Кураса НАН України, 2011. C. 244- 245.

11. Роулз Дж. Теория справедливости. Новосибирск, 1995. URL: https://gtmarket.ru/library/basis/6642/6643

12. Євтух В., Попок А. Конфлікт міжетнічний. Етносоціологія: терміни та поняття. Київ, 2003. С. 164.

13. Рудницька T. Етнічні особливості соціальнопрофесійного, галузевого та кваліфікаційного складу зайнятого населення України. Філософська і соціологічна думка. 1996. №1-2. С. $111-133$.

14. Свтух Б. Культурного поділу праці теорія. Етносоціологія: терміни та поняття. Київ, 2003. С. 178.

15. Ильин. В. Государство и социальная стратификация советского и постсоветского обществ $(1917$ - 1996 гг.): Опыт конструктивистско-структуралистского анализа. Сыктывкар: Сыктывкарский университет, Институт социологии РАН, 1996. C. 309-310.

\section{6. Социальное неравенство этнических групп:} представления и реальность. Авт. проекта и отв. ред. Л Дробижева. Москва: Academia, 2002. 480 с.

17. Дарендорф. Р. У пошуках нового устрою: лекції на тему політики свободи у XX ст. Київ: Видавничій дім «Києвомогилянська академія», 2006. 110 с.

18. Rogovsci R. Commerce and Coalitions: How Trade Affects Domestic Political Alignments Princeton: Princeton University Press, 1989, 208 p.

19. Tabb, William K. Unequal Partners: a Primer on Globalization. The New Press. 2002. 273 p.

20. Котигоренко В. Етнічні протиріччя і конфлікти в сучасній Україні: політологічний концепт. Київ: Світогляд, 2004. С. 152.

21. Етнополітичний конфлікт. URL: https://subject.com.ua/ political/dict/529.html 


\section{REFERENCES}

1. Burd'e P. Formy kapitala. [Bourdieu P. The Forms of Capital]. 1983. Retrevied from: https://gtmarket.ru/library/articles/260.

2. Van den Berghe, P. (1981). The Ethnic Phenomenon. Westport: Greenwood Press, 1981. 318 p.

3. Bonacich E. A (1972). Theory of Ethnic antagonism. The Split Labor Market. American Sociological Review. 1972. Vol.37. No.5 P.547 - 559 .

4. Arutyunyan YU., Drobizheva L., Soskopov A. (1999). Etnosociologiyayu. [Ethnosociology]. Moskva: Aspekt-Press. $271 \mathrm{~s}$.

5. Tishkov V. (2005). Rynochnaya ekonomika i etnicheskaya sreda. Obshestvo i ekonomika. [Market economy and ethnic environment. Society

and Economy]. №12. Retrevied from: http://www.demoscope.ru/weekly /2007/0271/analit03.php2.

6. Zvarich I. (2009). Etnopolitika v Ukrayini: regionalnij kontekst. [Ethnopolitics in Ukraine: regional context]. Kiyiv: Delta, 2009. $320 \mathrm{~s}$..

7. Kuras I.F. (2004). Etnopolitologiya. Pershi kroki stanovlennya. [Ethnopolitical science. The first steps of formation]. Kiyiv: Geneza. 736 s.

8. Majboroda O. (2005). Etnoprofesijna struktura ukrayinskogo suspilstva: tendenciyi zmin ta yihnij vpliv na mizhetnichni vidnosini [Ethnoprofessional structure of Ukrainian society: tendencies of changes and their influence on interethnic relations]. Naukovi zapiski Institutu politichnih i etnonacionalnih doslidzhen NAN Ukrayini. Kiyiv. Vip. 27. S. 30-48.

9. Arbyenina V. (2007). Etnosociologiya. [Ethnosociology]. Pidruchnik. Harkiv: Harkivskij nacionalnij universitet imeni V.N. Karazina, 160 s.

10. Etnopolitichni procesi v Ukrayini: regionalni osoblivosti [Ethnopolitical processes in Ukraine: regional features]: Monografiya. Kiyiv, Institut politichnih i etnonacionalnih doslidzhen im. I. F. Kurasa NAN Ukrayini, 2011. S. $244-245$ 
11. Roulz Dzh. (1995). Teoriya spravedlivosti. [The theory of justice]. Novosibirsk. Retrevied from: https://gtmarket.ru/ library/basis/6642/6643

12. Yevtuh V., Popok A. (2003). Konflikt mizhetnichnij. Etnosociologiya: termini ta ponyattya. [Interethnic conflict. Ethnosociology: terms and concepts]. Kiyiv, 2003. S. 164.

13. Rudnicka T. (1996). Etnichni osoblivosti socialnoprofesijnogo, galuzevogo ta kvalifikacijnogo skladu zajnyatogo naselennya Ukrayini. [Ethnic features of socio-professional, sectoral and qualification composition of the employed population of Ukraine]. Filosofska i sociologichna dumka. №1-2. S. 111-133.

14. Yevtuh B. (2003). Kulturnogo podilu praci teoriya. Etnosociologiya: termini ta ponyattya. [Cultural division of labor theory. Ethnosociology: terms and concepts]. Kiyiv. S. 178.

15. Ilin. V. (1996). Gosudarstvo i socialnaya stratifikaciya sovetskogo i postsovetskogo obshestv (1917 - 1996 gg.): Opyt konstruktivistsko-strukturalistskogo analiza. [The state and the social stratification of Soviet and post-Soviet societies (1917 1996): The experience of constructivist-structuralist analysis]. Syktyvkar: Syktyvkarskij universitet, Institut sociologii RAN. S. 309-310.

16. Socialnoe neravenstvo etnicheskih grupp: predstavleniya i realnost. [Social inequality of ethnic groups: perceptions and reality]. Avt. proekta i otv. red. L Drobizheva. Moskva: Academia, 2002. $480 \mathrm{~s}$.

17. Darendorf. R. (2006). U poshukah novogo ustroyu: lekciyi na temu politiki svobodi u XX st. [In search of a new system: lectures on the policy of freedom in the twentieth century]. Kiyiv: Vidavnichij dim «Kiyevo-mogilyanska akademiya». $110 \mathrm{~s}$.

18. Rogovsci R. (1989). Commerce and Coalitions: How Trade Affects Domestic Political Alignments Princeton: Princeton University Press, 1989, $208 \mathrm{p}$.

19. Tabb, William K. (2002). Unequal Partners: a Primer on Globalization. The New Press. 2002. 273 p. 
20. Kotigorenko V. Etnichni protirichchya i konflikti v suchasnij Ukrayini: politologichnij koncept. [Ethniic tensions and conflicts in contemorory Ukkaiene: a politogical Concept]. Kiyiv: Svitoglyad, 2004. S. 152.

21. Etnopolitichnij konflikt [Ethnopolitical conflict]. Retrevied from: https://subject.com.ua/political/dict/529.html

\section{АНОТАЦІЯ}

Узагальнено та проаналізована теоретикометодологічні засади впливу сочіально-економічних чинників на етнополітичні процеси в сегментованих суспільствах. Виявлено загальні закономірності та можливі наслідки від спрямованості їх розвитку для загальної політичної ситуації в краӥні. Найбільше уваги приділено конфліктологічним теоріям, функиіональному підходу, теоріям модернізації та культурологічним аспектам сочіально-економічної нерівності. Здійснено їх критичний аналіз. Наголошено на значному евристичному потенціалі існуючих теорій та необхідності їх практичного використання. Зазначено, щзо у більшості теоретичних підходів етнічність розглядається як символічний $i$ соціальний капітал, щзо може бути використаний для реалізації політичними акторами своїх політичних та економічних цүілей як всередині краӥні, так і поза ї̈ межами. У зв'язку з ичм вказано на потребу передбачити урахування сочіально-економічних

характеристик етнонаціональних груп у системі статистичної обробки даних Державним комітетом статистики України. Це дасть змогу постійно відстежувати процеси етносоціальної стратифікації в динаміці та забезпечить наукові дослідження відповідною інформачійною підтримкою. Зазначено, щзо враховуючи здобутки наявного наукового знання та з метою підвищуення ефективності державної етнонаціональної політики перспективним видається застосування підходу (умовно його можна назвати «status qио»), який передбачає перехід від парадигми «ми - вони» до парадигми «я і ми». Його 
основне завдання - досягти того, щуоб кожний громадянин міг вільно і в повній мірі брати участь у суспільно-політичному житті нації, мав можливості соціальної мобільності, одночасно зберігаючи свою власну регіональну, локальну, національно-культурну, духовно-релігійну та особистісну ідентичності.

Ключові слова: етнополітика, теоретико-методологічні підходи, соцуіально-економічні чинники етнічної мобілізації, етнічність.

\section{АННОТАЦИЯ}

Обобщень и проанализированы теоретикометодологические основы влияния сочиально-экономических факторов на этнополитические процессы в сегментированных обществах. Выявлены общие закономерности и возможные последствия от направленности их развития для общей политической ситуации в стране. Наибольшее внимание уделено конфликтологические теориям, функииональному подходу, теориям модернизации и культурологическим аспектам сочиально-экономического неравенства. Осущуествлен их критический анализ. Отмечен значительный эвристическом потенциале сущуествующих теорий, а также необходимость их практического использования. Отмечено, что в большинстве научных подходов этничность рассматривается как символический и социальный капитал, который может быть использован для реализации политическими актерами своих эгалитарных иелей как внутри страны, так и за ее пределами. В связи с этим указано на необходимости предусмотреть учет социально-экономических характеристик этнонациональных групп в системе статистической обработки данных Государственным комитетом статистики Украины. Это позволит постоянно отслеживать процессь этносоциальной стратификации в динамике и обеспечит научные исследования соответствующей информационной поддержкой. Отмечено, 
что учитывая достижения имеющегося научного знания и с цельюю повышения эффрективности государственной этнонациональной политики перспективным представляется применение подхода (условно его можно назвать «status quо»), который предусматривает переход от парадигмы «мы - они» к парадигме «я и мыл». Его основная задача - добиться того, чтобы каждый гражданин мог свободно и в полной мере участвовать в общественно-политической жизни нации, имел возможности социальной мобильности, одновременно сохраняя свою собственную региональную, локальную, национально-культурную, духовно-религиозную и личностную идентичности.

Ключевые слова: этнополитика, теоретикометодологические подходы, социально-экономические факторы этнической мобилизачии, этничность. 